Loyalitas Kreativitas
Aldi Masyarakat Kreatif

\title{
MANAJEMEN PENGETAHUAN REKAM JEJAK DIGITAL KINERJA KELURAAHAN PAMULANG BARAT
}

\author{
Risza Putri Elburdah, Derita Qurbani, Hestu Nugroho Warasto, Sutiman, Sulaiman \\ Dosen Prodi Manajemen Fakultas Ekonomi Universitas Pamulang \\ Email : risza01022@unpam.ac.id, derita01582@unpam.ac.id, \\ dosen01848@unpam.ac.id,Dosen01673@unpam.ac.id \\ dosen01902@unpam.ac.id
}

P-ISSN 2722-2101, E-ISSN 2722-4201

Program Studi Ekonomi Manajemen Universitas Pamulang

Jurnal LOKABMAS Kreatif Vol.02,No.02.Juli 2021 Hal.44-50

Email:jurnalkreatif.manajemen@gmail.com

\begin{abstract}
ABSTRAK
Tujuan dari kegiatan Pengabdian Kepada Masyarakat ini adalah untuk melaksanakan salah satu Tri Dharma Perguruan Tinggi. Selain itu, melalui kegiatan Pengabdian Kepada Masyarakat ini, diharapkan menjadi kesempatan bagi pegawai Kelurahan Pamulang Barat untuk berdiskusi dengan narasumber terkait dengan manajemen pengetahuan rekam jejak digital kinerja. Tujuan dari kegiatan Pengabdian Kepada Masyarakat ini adalah untuk melaksanakan salah satu Tri Dharma Perguruan Tinggi dan tujuan utamanya adalah untuk memberikan gambaran strategi yang dapat dilakukan dalam upaya melakukan pemetaan pengetahuan yang ada di lingkup kelurahan. Selain itu diharapkan dengan pengabdian kepada masyarakat ini keberadaan perguruan tinggi dapat memberikan kontribusi besar kepada pengembangan dan penerapan keilmuan kepada masyarakat

Metode yang kegiatan yang dilaksanakan adalah kami mendatangi langsung ke lokasi PKM yaitu di Kelurahan Pamulang Barat. Hasil pengabdian kepada masyarakat yang diperoleh yakni terpetakannya pengetahuan dan pengelolaan pengetahuan yang akan dijadikan rekam jejak digital kinerja. Ilmu yang didapatkan pada Pengabdian Kepada Masyarakat kali ini diharapkan mampu memberikan semangat baru bagi dosen dalam upaya mengembangkan diri memberikan pengarahan, penyampaian materi dan motivasi serta berkontribusi bagi generasi muda baik di dalam lingkungan kampus, keluarga dan masyarakat secara luas.
\end{abstract}

\section{Kata kunci : Manajemen Pengetahuan, Kinerja}

\begin{abstract}
The purpose of this Community Service activity is to carry out one of the Tri Dharma Perguruan Tinggi. In addition, through this Community Service activity, it is hoped that it will become an opportunity for employees of the Kelurahan Pamulang Barat to discuss with sources related to knowledge management of digital performance track records. The purpose of this Community Service activity is to carry out one of the Tri Dharma of Higher Education and its main purpose is to provide an overview of strategies that can be carried out in an effort to map the knowledge that is within the Kelurahan. In addition, it is hoped that with this community service, the existence of universities can make a major contribution to the development and application of science to the community.

The method by which the activity was carried out was that we went directly to the PKM location, namely in the Kelurahan Pamulang Barat. The results of community service obtained
\end{abstract}


Loyalitas Kreativitas
Aldi Masyarakat Kreatif
P-ISSN 2722-2101, E-ISSN 2722-4201

Program Studi Ekonomi Manajemen Universitas Pamulang

Jurnal LOKABMAS Kreatif Vol.02,No.02.Juli 2021 Hal.44-50

Email:jurnalkreatif.manajemen@gmail.com

are mapping of knowledge and knowledge management which will be used as a digital track record of performance. The knowledge gained in Community Service this time is expected to be able to provide new enthusiasm for lecturers in an effort to develop themselves in providing direction, delivery of material and motivation as well as contributing to the younger generation both within the campus, family and society.

\section{Keywords: Knowledge Management, Performance}

\section{PENDAHULUAN}

Knowledge management terdiri dari dua jenis pengetahuan: explicit knowledge, pengetahuan yang dapat dipelajari secara jelas dalam bentuk tetulis dan lisan, seperti prosedur, peraturan, dan kebijakan, dan tacit knowledge, pengetahuan yang sifatnya melekat dalam tiap individu seperti, nilainilai, keyakinan karyawan, pengalaman, dan pengetahuan knowhow. Pengetahuan adalah pengalaman terstruktur, nilai, informasi kontekstual dan wawasan pakar yang menyediakan kerangka kerja untuk mengevaluasi dan menggabungkan pengalamaan dan pengetahuan baru yang menghasilkan tindakan serta menghasilkan keputusan yang lebih baik dan menghasilkan input yang efektif pada dialog dan kreativitas organisasi. Kota Tangerang Selatan merupakan daerah otonom yang terbentuk pada akhir tahun 2008 berdasarkan Undang-undang Nomor 51 Tahun 2008 tentang Pembentukan Kota Tangerang Selatan di Propinsi Banten tertanggal 26 November 2008. Pembentukan daerah otonom baru tersebut, yang merupakan pemekaran dari Kabupaten Tangerang, dilakukan dengan tujuan meningkatkan pelayanan dalam bidang pemerintahan, pembangunan, dan kemasyarakatan serta dapat memberikan kemampuan dalam pemanfaatan potensi daerah. $\mathrm{U}$ atau mengambil keputusan yang sesuai dengan dunia kerja pilihannya itu.

Setiap individu harus tahu bagaimana cara memanfaatkanpengetahuan untuk meningkatkan keunggulan kompetitif bagi dirinya sendiri maupun orang lain. Organisasi harus mampu memanfaatkan kekuatan dan peluang serta memahami kelemahan dan ancaman agar mampu bertahan dalam persaingan. Untuk melakukan pemanfaatan dan pengembangan pengetahuan, diperlukan pengelolaan dengan aktivitas berbagi pengetahuan.

Untuk meningkatkan pelayanan kepada masyarakat para pegawai kelurahan perlu memetakan dan mengetahui pengetahuanpengetahuan apa saja yang ada pada setiap pegawai. Hal ini bertujuan agar pengetahuan - pengetahuan tersebut tidak hilang apabila pegawai tersebut memasuki pensiun atau dipindahtugaskan ke kantor kelurahan wilayah lain. Pengetahuan adalah segala sesuatu yang diketahui dan pernah dipelajari dari lingkungan sekitar. Hal ini dapat meliputi mata pelajaran, tradisi, informasi dan keterampilan. Semakin sering manusia belajar, berfikir dan bertanya, semakin bertambah pula pengetahuan yang dimilikinya. Pengetahuan sangat bermanfaat bagi kehidupan manusia baik pada masa sekarang maupun masa depan. Hal itu berarti pengetahuan menjadi faktor penting bagi seseorang maupun organisasi untuk dapat bersaing di lingkungan yang semakin kompetitif. Setiap individu harus tahu bagaimana cara memanfaatkanpengetahuan untuk meningkatkan keunggulan kompetitif bagi dirinya sendiri maupun orang lain. Organisasi harus mampu memanfaatkan kekuatan dan peluang serta memahami kelemahan dan ancaman agar mampu bertahan dalam persaingan. Untuk melakukan pemanfaatan dan pengembangan pengetahuan, diperlukan pengelolaan dengan aktivitas berbagi pengetahuan.

Ada tiga unsur pembentuk Knowledge Management (KM) yaitu orang, proses, dan 
Loyalitas Kreativitas
Aldi Masyarakat Kreatif
P-ISSN 2722-2101, E-ISSN 2722-4201

Program Studi Ekonomi Manajemen Universitas Pamulang

Jurnal LOKABMAS Kreatif Vol.02,No.02.Juli 2021 Hal.44-50

Email:jurnalkreatif.manajemen@gmail.com teknologi seperti ditunjukkan pada Gambar 1. Orang merupakan aktor penentu dalam mengelola KM. Proses dan teknologi merupakan alat bantu orang yang mendukung 4 proses yaitu: penciptaaan (KM-creation), pembauran (KMassimilation), penyebaran (KMdissemination), dan penerapan pengetahuan (KM-application) dalam organisasi/perusahaan (Tjakraatmadja dkk, 2015). Penciptaan pengetahuan merupakan proses memperbaiki pengetahuan yang sudah ada baik melalui proses menemukan pengetahuan yang masih baru atau melalui proses merefleksikan diri atas pengalaman yang pernah dialami. Sebagai contoh yaitu karyawan memiliki sikap keterbukaan dan kerendahan hati pada saat mendeteksi adanya kesalahan kerja dan berusaha untuk melakukan perbaikan (lesson learned). Bahkan kesalahan kerja tersebut dapat didokumentasikan dan dibagikan dalam organisasi, supaya orang lain dapat belajar dari kesalahan tersebut dan tidak akan mengulang kesalahan yang sama di masa yang akan datang.

Selain untuk menghindari kesalahan tersebut, manajemen pengetahuan juga membantu untuk mengelola kejadiankejadian atau prestasi yang dicapai selama masa kepemimpinan. Sosialisasi merupakan proses menciptakan pengetahuan taksit melalui berbagi pengetahuan atau pengalaman secara langsung antara orang yang satu dengan yang lain (one-to-one). Contoh: seorang staf senior membimbing seorang staf yang baru bekerja (yunior), rapat tim kerja dan/ antar perorangan. Pola ini dapat terjadi untuk pembelajaran secara teknis maupun dalam membangun budaya kerja atau kebiasaan-kebiasaan dalam perusahaan.

Setiap media sosial memiliki rekam jejak yang berisikan informasi atau data historis mengenai hasil penelusuran seseorang yang disebut dengan jejak digital. Dalam penelitian sebelumnya yang dilakukan oleh Wang [et al.] (2016) mengenai pelacakan jejak digital rujukan utama artikel ilmiah yang ditemukan dari platform jejaring sosial yang diikuti olej bookmark atau URL di ketik di mesin pencarian umum atau browser. Jejak digital dapat dengan mudah dilacak dari berbagai sistem pencarian atau penelusuran sumber informasi secara online. Media sosial memiliki peran yang penting dalam penelusuran informasi yang terintegrasi dengan akun dan situs ataupun platform google. Rekam jejak digital inilah sebagai penentu baik atau buruknya kinerja di masa depan. Melalui rekam jejak ini organisasi dapat melakukan evaluasi ataupun pembelajaran.

\section{RUMUSAN MASALAH}

Berdasarkan uraian analisis situasi permsalahan, maka dapat diperoleh rumusan masalah yang dihadapi mitra adalah :

1. Bagaimana manajemen pengetahuan di Keluarahan Pamulang Barat?

2. Bagaimana pengelolaan rekam jejak digital Kelurahan Pamulang Barat?

3. Bagaimana menentukan pemetaan jejak digital kinerja Kelurahan Pamulang Barat

\section{TUJUAN KEGIATAN}

1. Berdasarkan uraian analisis situasi permsalahan, maka tujuan dari Pengabdian Kepada Masyarakat adalah :

a. Untuk mengetahui manajemen pengetahuan di Keluarahan Pamulang Barat.

b. Untuk mengetahui pengelolaan rekam jejak digital Kelurahan Pamulang Barat

c. Untuk menentukan pemetaan jejak digital kinerja Kelurahan Pamulang Barat

\section{TINJAUAN PUSTAKA}

Pengetahuan adalah aset tidak berwujud yang hampir tidak mungkin untuk ditiru dan dipandang sebagai instrumen kompetitif yang harus dikelola secara efektif oleh setiap organisasi. Meskipun banyak yang telah membahas pentingnya pengetahuan dalam sebuah manajemen, 
Loyalitas Kreativitas
Aldi Masyarakat Kreatif

tetapi relatif sedikit yang memperhatikan bagaimana proses pembuatan dan pengelolaan pengetahuan. Dalam proses pembuatan pengetahuan ini, kemudian dapat ditarik perbedaan pengetahuan menjadi dua kategori yaitu, pengetahuan tacit dan pengetahuan ekplisit.

Pengetahuan tacit merupakan pengetahuan yang ada di dalam pikiran setiap individu sesuai dengan pemahaman, keahlian, dan pengalaman seseorang. Pengetahuan tacit merupakan pengetahuan yang sulit untuk diformulasikan dan dikomunikasikan, karena berada di dalam benak masing - masing orang. Pengetahuan yang ada dalam diri seseorang, tampak seperti sebuah gunung es. Berdasarkan pengertiannya, maka pengetahuan tacit dapat dikategorikan sebagai pengetahuan personal. Alavi (2001) mengungkapkan, eksplisit dimensi pengetahuan (selanjutnya disebut sebagai pengetahuan eksplisit) diartikulasikan, dikodifikasi, dan dikomunikasikan dalam bentuk simbolik dan/atau bahasa alami. Contohnya pembelian sebuah produk elektronik, pasti disertai petunjuk pemakaian.

Petunjuk pemakaian itu merupakan pengetahuan seputar pengoperasian produk tersebut. Penerapan pengetahuan eksplisit lebih mudah, karena pengetahuan yang diperoleh dalam bentuk tulisan atau rekaman yang telah didokumentasikan, sehingga karyawan dapat mempelajarinya secara mandiri. Pengetahuan eksplisit dalam penelitian ini adalah prosedur kerja dan teknologi. Prosedur kerja adalah tugas dan tanggung jawab yang telah diberikan kepada karyawan yang bersifat formal. Pengetahuan eksplisit ditandai, menurut berbagai penelitian, dengan kemampuannya untuk dinyatakan sebagai kata atau nomor, dalam bentuk data tercetak, formula ilmiah, manual, file komputer, dokumen, paten, dan prosedur standar atau titik awal universal yang dapat dengan mudah ditransfer dan disebarkan.) Pengetahuan adalah proses, maka secara tersirat fokus manajemen adalah pada aliran pengetahuan dan proses penciptaan, berbagi, dan distribusi pengetahuan" (Alavi \& Leidner, 200; Sundiman \& Idrus, 2015). Disinilah peran penting dari teknologi informasi, mengingat canggihnyateknologi saat ini. Misalnya, internet, intranet, browser, extranet, data mining teknik, gudang data, dan agen software. Bagian terpenting dalam knowledge management adalah mendorong individu-individu dalam organisasi untuk konsisten dalam melakukan perekaman jejak digital.

\section{METODE PELAKSANAAN}

Metode kegiatan pengabdian kepada masyarakat ini dibagi menjadi beberapa tahap. Tahap pertama adalah identifikasi masalah yang dilakukan sebagai langkah awal untuk merumuskan apa saja yang akan dijadikan bahan untuk perancangan sistem dan materi pelatihan dalam kegiatan pengabdian kepada masyarakat ini.

Tahap berikutnya yaitu melakukan survei lapangan ke kantor Kelurahan Pamulang Barat. Tim pelaksana kemudian melakukan proses wawancara dan diskusi dengan pihak pegawai kelurahan untuk mengidentifikasi permasalahan yang ada dalam lingkungan kerja terkait perekaman aktivitas kegiatan program kerja untuk kemudian merumuskan solusi dan penyelesaiannya serta menentukan keluaran yang diharapkan oleh mitra. Pada tahap ini anggota tim pelaksana berdiskusi menentukan tema dan materi yang akan disampaikan, bahan dan alat yang diperlukan, serta persiapan teknis lainnya yang dibutuhkan untuk kelancaran pelaksanaan kegiatan pengabdian kepada masyarakat ini. Permasalahan yang ditemukan pada Kelurahan Pamulang Barat adalah belum mengetahui tata Kelola perekaman jejak digital kinerja.

Tahap berikutnya adalah pelaksanaan kegiatan. Kegiatan ini dilaksanakan di tempat mitra, yaitu di Kantor Kelurahan Pamulang Barat, pada hari Senin 29 Maret 2021 sampai dengan hari Rabu 31 Maret 2021 mulai pukul 09.00 sampai pukul 
Loyalitas Kreativitas Aldi Masyarakat Kreatif
P-ISSN 2722-2101, E-ISSN 2722-4201

Program Studi Ekonomi Manajemen Universitas Pamulang Jurnal LOKABMAS Kreatif Vol.02,No.02.Juli 2021 Hal.44-50 Email:jurnalkreatif.manajemen@gmail.com
14.00 WIB. Kegiatan ini dilakukan dengan memberikan penyuluhan kepada pegawai kelurahan Penyampaian materi menggunakan metode presentasi dengan media Microsoft Power Point. Peserta yang mengikuti kegiatan ini sebanyak 20 orang.

Pihak mitra, yaitu Lurah PAmulang Barat menyediakan ruang kegiatan yang memadai dan nyaman. Hal yang perlu diperhatikan yaitu cara mengatur (formasi) tempat duduk. Karena masih berada di masa pandemi, maka peserta dibatasi hanya 20 orang dan pengaturan tempat duduk serta pelaksanaan kegiatannya disesuaikan dengan protokol kesehatan (duduk diatur agar berjarak, tetap menggunakan masker, mencuci tangan setelah kegiatan, dan protokol kesehatan lainnya).

Untuk menunjang lancarnya pelaksanaan kegiatan ini, diperlukanbeberapa alat bantu/media pembelajaran tertentu, yaitu :

1) LCD (Liquid Crystal Display)

2) Laptop

3) Spidol

4) White board

5) Buku catatan

Tahap terakhir dalam kegiatan pengabdian kepada masyarakat ini yaitu tindak lanjut dari pelaksanaan kegiatan ini. Pada tahap ini dilakukan diskusi atau tanya jawab tentang permasalahan seputar manajemen pengetahuan rekam jejak digital kinerja

Kegiatan pengabdian kepada masyarakat ini bertujuan untuk membuat pegawai kelurahan menyadari pentingnya manajemen pengetahuan rekam jejak digital dalam peningkatan kinerja organisasi Target lain yang ingin dicapai dalam kegiatan pengabdian kepada masyarakat ini adalah timbulnya motivasi dalam diri tim pelaksana kegiatan untuk membuat media digital khusus sebagai wadah tata Kelola pengetahuan dan mempublikasikan hasil tulisan tersebut ke dalam jurnal Pengabdian Kepada Masyarakat.

\section{HASIL DAN PEMBAHASAN \\ Hasil Kegiatan}

Pegawai Kelurahan menganggap budaya yang ada dalam organisasi sesuai dengan keinginannya, mereka akan memberikan sikap positif dan mendukung organisasi dalam mencapai tujuan. Sebaliknya, pegawai akan bersikap negatif dan acuh terhadap kemajuan organisasi jika budaya yang ada tidak sesuai dengan keinginannya. Oleh karena itu manajemen pengetahuan rekam jejak digital merupakan hal baru bagi mereka, namun melihat dampak yang dapat dihasilkan untuk kemajuan organisasi seluruh pegawai sepakat untuk terbiasa melakukan rekam jejak digital .Sikap pegawai yang mendukung proses berbagi pengetahuan sangat dibutuhkan, karena hal tersebutmerupakan upaya untuk menciptakan ide-ide baru, meningkatkan produktivitas dan mencapai visi, misi serta tujuan organisasi

\section{Pembahasan}

Untuk melaksanakan kegiatan PKM ini digunakan beberapa metode penyuluhan yaitu sebagai berikut :

a. $\quad$ Metode Ceramah $\rightarrow$ Metode yang digunakan dalam penyuluhan ini yaitu penyuluhan dengan memberikan ceramah atau presentasi dengan tema "Manajemen Pengetahuan Rekam Jejak Digital Kinerja Kelurahan Pamulang Barat"

b. Metode Diskusi Dan Tanya Jawab $\rightarrow$ Setelah sesi pemberian materi selesai, maka dilanjutkan dengan sesi diskusi dengan tanya jawab. Hasil yang didapatkan adalah Kelurahan belum mengetahui cara melakukan manajemen pengetahuan pada media digital, sehingga pelaksanaan PKM ini menjadi suatu kebutuhan. Dalam pelaksanaanya kedepan Kelurahan Pamulang Barat akan lebih sering memperbaharui setiap pengetahuan baru atau kegiatan yang ada, sebagai media pembelajaran kedepannya. 
Loyalitas Kreativitas

Aldi Masyarakat Kreatif
P-ISSN 2722-2101, E-ISSN 2722-4201

Program Studi Ekonomi Manajemen Universitas Pamulang

Jurnal LOKABMAS Kreatif Vol.02,No.02.Juli 2021 Hal.44-50

Email:jurnalkreatif.manajemen@gmail.com c. $\quad$ Metode Simulasi $\rightarrow$ Penyuluhan ini juga menggunakan metode simulasi, sehingga peserta langsung dapat mempraktekan apa yang sudah disampaikan. Apabila ada kendala yang dirasakan maka langsung dibantu pada saat pelaksanaan PKM. Simulasi ini penting dilakukan untuk mengetahui seberapa besar tingkat pengetahuan dan ilmu yang diserap oleh pegawai kelurahan Pamulang Barat.

\section{KESIMPULAN DAN SARAN Kesimpulan}

Pelaksanaan kegiatan Pengabdian Kepada Masyarakat oleh Lembaga Penelitian dan Pengabdian Masyarakat (LPPM) Universitas Pamulang yang dilakukan oleh dosen-dosen Program Studi Manajemen telah berjalan dengan lancar dan mendapat sambutan positif dari Pak Lurah dan pegawai Kelurahan Pamulang Barat. Harapan kami selaku dosen dengan adanya kegiatan PKM ini dapat menambah ilmu yang bermanfaat dalam hal sikap disiplin dan tanggung jawab.

Dalam laporan kegiatan PKM ini dapat disimpulkan bahwa Kelurahan Pamulang Barat belum melakukan pengelolaan pengetahua kinerja dalam media digital sebagau bentuk rekam jejak digital. Sehingga tidak banyak masyarakat yang mengetahui mengenai program kerja atau kegiatan yang dilaksanakan. Hal ini dapat berakibat minimnya informasi yang bisa diketahui oleh masyarakat. Selain itu apabila kedepannya terdapat suatu kejadian serupa tidak bisa dijadikan sebagai suatu pembelajaran.

Akhirnya, kami mengucapkan banyak terimakasih kepada seluruh pihak yang telah mendukung dan berkontribusi dalam kegiatan PKM ini dan kami memohon maaf apabila dalam kegiatan PKM ini banyak ditemukan kekurangan dan kesalahan.

\section{Saran}

Berdasarkan hasil kegiatan PKM yang sudah dilakukan, maka kami dari team Dosen Universitas Pamulang memberikan saran yaitu sebagai berikut :

1. Kelurahan Pamulang Barat menunjuk seseorang yang bertugas untuk mengelola rekam jejak kinerja, yang selanjutnya diberikan pelatihan lanjut pengelolan pengetahuan dalam media digital.

2. Pengelolaan manajemen pengetahuan dilakukan pada media digital yang digunakan sebagai portal informasi yang sering dilakukan pemuktahiran data. Penggunaan kode-kode (hashtag) dalam pemutakhiran jejak kinerja sangan disarankan untuk dilakukan.

\section{DAFTAR PUSTAKA}

1. EP, Sari. (2020). PENGARUH AKTIVITAS PENELUSURAN JEJAK DIGITAL DI YOUTUBE BAGI GENERASI MILLENIAL.- JURNAL BIBLIOTIKA.

2. RP, Elburdah, B Oktrima (2020). PENGARUH COMMUNITY OF PRACTICE PADA IMPLEMENTASI KNOWLEDGE MANAGEMENT PADA KANTOR KELURAHAN REMPOA - JURNAL LOKABMAS KREATIF

3. RP, Elburdh. (2020) PENGARUH KEPEMIMPINAN DAN KOMPENSASI TERHADAP KINERJA KARYAWAN PADA PT. PENTA ARTHA IMPRESSI AREA TANGERANG SELATAN- Jurnal Semarak.

4. RP, Elburdah. (2018).PENGARUH GAYA KEPEMIMPINAN DAN KEPUASAN KERJA TERHADAP 
Loyalitas Kreativitas

Aldi Masyarakat Kreatif
P-ISSN 2722-2101, E-ISSN 2722-4201

Program Studi Ekonomi Manajemen Universitas Pamulang

Jurnal LOKABMAS Kreatif Vol.02,No.02.Juli 2021 Hal.44-50

Email:jurnalkreatif.manajemen@gmail.com
KINERJA PEGAWAI DINAS PETERNAKAN DAN KESEHATAN HEWAN PROVINSI RIAU - Jurnal Mandiri: Ilmu Pengetahuan, Seni, dan Teknologi, 2018

5. Elburdah, R. P., Pasaribu, V. L. D., Rahayu, S., Septiani, F., \& Metarini, R. R. A. (2021). Mompreneur Penopang Perekonomian Keluarga Di Masa Pandemi Covid-19 Dengan Bisnis Online Pada Kelurahan Pondok Benda. Abdi Laksana: Jurnal Pengabdian Kepada

Masyarakat, 2(1), 75-82.

6. Sopandi.2016.Implementasi Knowledge Management Pada Perguruan Tinggi. Jurnal Administrasu Pendidikan.

7. Trivellas, P., Akrivouli, Z., Tsifora, E., Tsoutsa, P. 2015. The Impact of Knowledge Sharing Culture on job Satisfaction in Accounting Firm with Mediating Effect of general Competencies. E-journal Procedia Economic and Finance Elsevier. 19: 238-24

8. Pasaribu, V. L. D., Agrasadya, A., Shabrina, N., \& Krisnaldy, K. (2020). Menjadi Enterpreneur Muda Yang Memiliki Jiwa Leadership Untuk Menghadapi Masa Depan. Abdi Laksana: Jurnal Pengabdian Kepada Masyarakat, 1(1).

9. Pasaribu, V. L. D., Susanti, F., \& Hartuti, E. T. K. (2019). Memotivasi Siswa dan Siswi SMK Letris Indonesia di Dalam Menentukan Pilihan Untuk Melanjutkan Pendidikan Atau Bekerja Setelah Lulus Sekolah. Jurnal Pengabdian Dharma Laksana, 1(2), 161-172.
10. Pasaribu, V. L. D., Sulaiman, S., Sutiman, S., Thaharudin, T., \& Purnomo, B. Y. (2020). Pengenalan Letak Posyandu Terdekat Dikelurahan Pisangan Dengan Manajemen Pemasaran Revolusi 4.0 Untuk Meningkatkan Pengetahuan Masyarakat Letak Dan Fungsi Posyandu Terdekat Pada Kelurahan Pisangan. Dedikasi Pkm, l(1), 105110.

11. Pasaribu, V. L. D., Oktrima, B., Prabowo, B., Arianto, N., \& Haryoko, U. B. (2020). Progam Pendampingan Dan Penyelenggaraan Pendidikan Anak Pada Usia Dini Terhadap Prestasi Belajar Dilingkungan Rt 020 Rw 009. Kel Giri Peni. Kec Wates. Yogyakarta. Jurnal Lokabmas Kreatif, 1(1), 71-75.

12. Pasaribu, V. L. D., Jannah, M., Fazar, M., Putra, S. P., Monalisa, M., \& Sofa, M. (2021). MENINGKATKAN PRODUKTIVITAS USAHA DIMASA PANDEMI PADA IBU PKK RT 004/003 KELURAHAN SAWAH BARU CIPUTAT, TANGERANG SELATAN. Abdi Laksana: Jurnal Pengabdian Kepada Masyarakat, 2(2), 295-301.

13. Pasaribu, V. L. D., Yuniati, H. L., Pranata, R., Sembayu, R., Purba, S. M., \& Nurbayani, T. T. A. (2021). MANAJEMEN KEUANGAN UNTUK MENGHADAPI DAN BERTAHAN DI ERA COVID 19. Jurnal Abdimas Tri Dharma Manajemen, 2(2), 12-18.

14. Pasaribu, V. L. D., Dwiyatni, A., Sabina, C., Ridwan, M., Gunawan, D. D., \& Noviani, B. C. (2021). EVALUASI PENERAPAN 3M DIMASA PANDEMIC COVID 19. Jurnal Abdimas Tri Dharma Manajemen, 2(2), 54-60. 
Loyalitas Kreativitas

Aldi Masyarakat Kreatif
P-ISSN 2722-2101, E-ISSN 2722-4201

Program Studi Ekonomi Manajemen Universitas Pamulang Jurnal LOKABMAS Kreatif Vol.02,No.02.Juli 2021 Hal.44-50 Email:jurnalkreatif.manajemen@gmail.com
15. Pasaribu, V. L. D., Syafei, A. N., Farhan, A., Aufaizah, A., Irani, C., \& Firtiayani, S. R. (2021). PENGARUH DISPLIN PROTOKOL KESEHATAN TERHADAP PENCEGAHAN PENULARAN VIRUS COVID-19. Jurnal Abdimas Tri Dharma Manajemen, 2(2), 91-98.

16. Priadi, A., Pasaribu, V. L. D., Virby, S., Sairin, S., \& Wardani, W. G. (2020). Penguatan Ekonomi Kreatif Berbasis Sumber Daya Desa Dikelurahan Rempoa. Abdi Laksana: Jurnal Pengabdian Kepada Masyarakat, 1(3), 356-35

\section{DOKUMENTASI KEGIATAN}
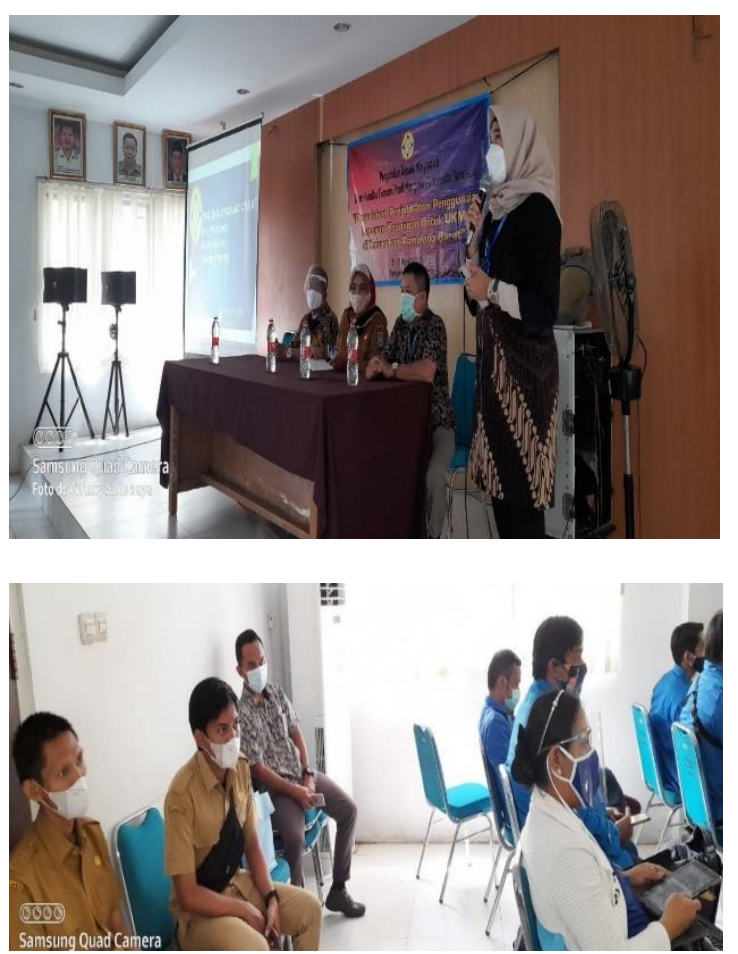
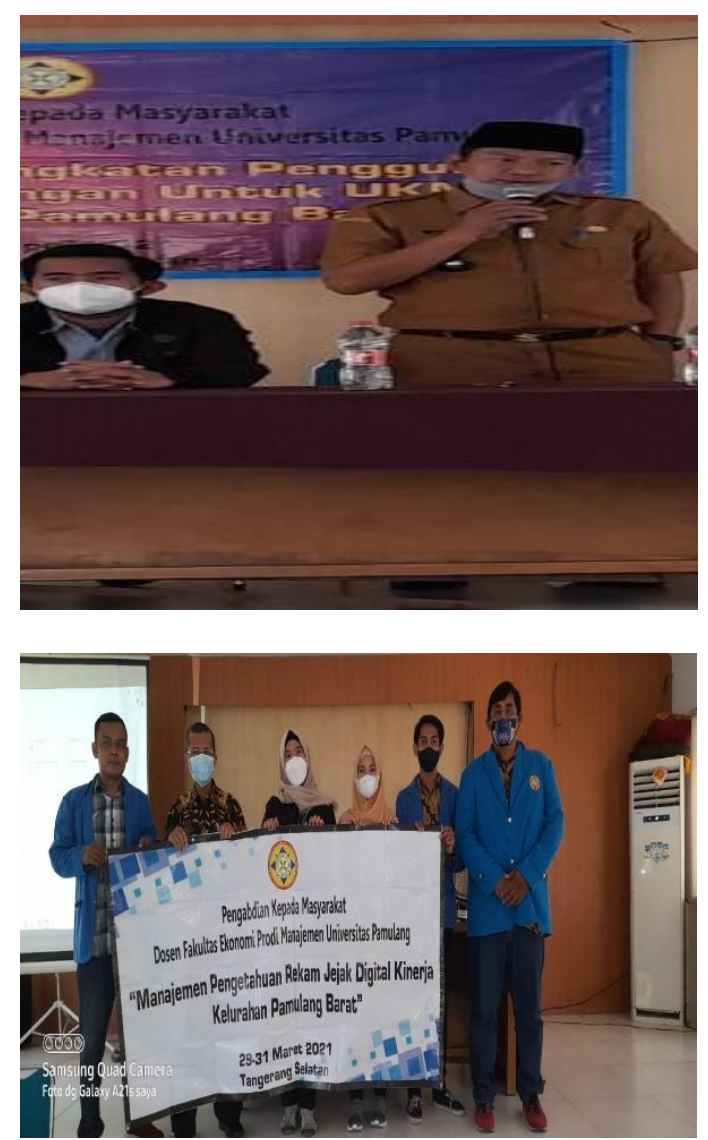